\title{
From public policy to pure anthropology: A genealogy of the idea of the hybrid economy
}

\section{Chris Gregory}

\section{The argument}

I have carried out fieldwork with Aboriginal people in Papua New Guinea, Fiji and India and it is from this comparative perspective that I cast my critical eye over Jon Altman's concept of the hybrid economy. My title is a double twist on a critique Jon wrote of Nic Peterson's notion of demand sharing (Altman 2011a). My critique is offered in the same spirit: to critique Jon's ideas, not to celebrate or denigrate him as a person. I make three points.

First, pure anthropology must precede public policy, description must precede prescription. When the issue concerns an economic policy, this means that study of comparative ethnography, economy history, and historical geography must come first. Such is the approach of 19thcentury political economy and 20th-century economic anthropology. Mainstream economics does not share this assumption. Their free market policies come first; their abstract ahistorical theories provide the justification for policies of this kind. Jon is actively engaged in policy whereas I am not but we are in agreement when it comes to 
the primacy of pure anthropology. We both agree that pure economic anthropology provides a radical empirical critique of the conventional wisdom that informs mainstream economics.

Second, pure anthropology must be theoretically informed. Again, we agree, but it is the specificity of Jon's notion of the hybrid economy that I question. Jon's theory was inspired by Yang's (Yang 2000) but Jon claims (Altman 2009: 319) that his theory is 'radically different' to Yang's because fiscal transfers from the state loom large in Australia. This argument was true prior to 1996 but it is no longer true today. Development policy has undergone a revolution: incentives in the form of fiscal transfers have become the norm (Ballard 2012). Jon's conceptual framework is, therefore, completely general and is one offspring in a long line of thinking about the idea of the economy. Yang's 2000 theory of economic hybridity is a critique of 1970s articulation theory; articulation theory, in turn, was a critique of 1960s tribal economy which abstracted from the historical fact of colonisation; tribal economy, in turn, was a critique of earlier political economy, a Eurocentric theory that universalised commodity exchange, and so on up the intellectual lineage and back in time. If fiscal transfers no longer define the specificity of economic hybridity in Australia then what are the defining characteristics of the Australian case? This is an extremely difficult empirical question which I will not attempt to address in this short essay.

This brings me to my third point. Jon, like most anthropologists, is wary of binary thinking. Indeed, he sees his conception of economic hybridity as a means of transcending 'false binaries'. But binary thinking is absolutely essential to good conceptual thought. The binaries in Jon's conception of hybridity are loose and incomplete. Logical errors can sometimes be fatal for a theory but in this happy case, they are not. My critique of Jon's conceptual framework makes it more rigorous. This essay, then, will endeavour to tighten Jon's binaries and to identify an important missing category in his analysis. 


\section{A critique of Altman's concept of economic hybridity}

Jon's (Altman 2001) theory began with a simple list. He distinguishes three 'conceptual sectors' - state, customary, market - and four 'cross-cutting cleavages' between these three sectors whose 'linkages and interdependencies' define the 'nature of hybridity'. Thus we have seven items in the list:

1. State

2. Customary

3. Market

4. State and customary

5. State and market

6. Customary and market

7. State and customary and market.

In 2005 the seven items in the list is reformulated as a Venn diagram (Altman 2005). This is shown as Vl in Fig. 3.1. This Venn diagram goes through another eight variations over the next six years. These are shown as V2 to V9 in Fig. 3.1. All nine variations contain minor logical and conceptual problems of one kind or another. The only constant is the numbering from 1 to 7 but to the extent that this numbering refers to the seven items in the list it is a mis-specification. From the point of view of strict binary logic, there are three sectors and eight segments, 11 categories in total. This poses the crucial question of the socioeconomic interpretation of the 11 categories and, in particular, of the eighth segment shown in Vl as mere decorative background. V1 poses other questions: Does the larger relative size of the state circle have any significance? Is it supposed to represent the idea that this sector is dominant in some sense? Before we try to answer these questions it is necessary to look at the other variations. 
V1

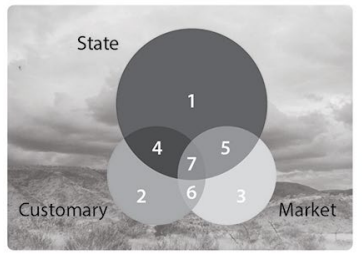

V4

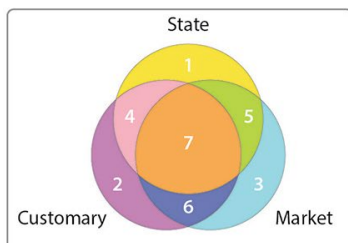

V7

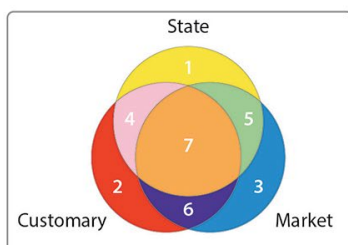

V2

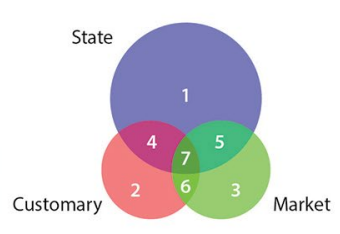

V5

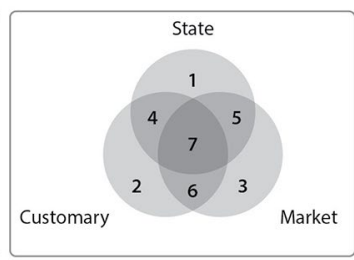

V8

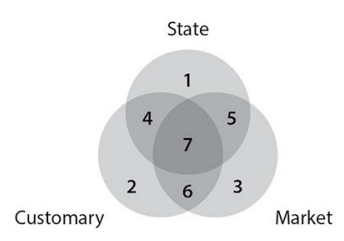

V3

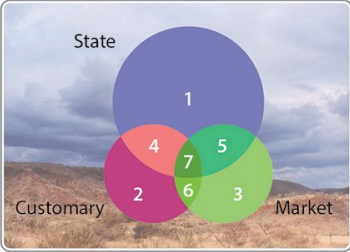

V6

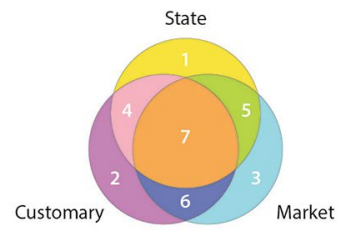

V9

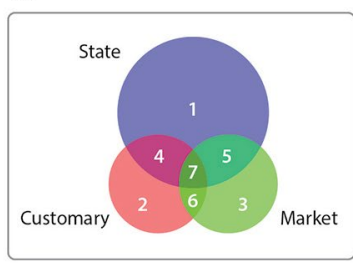

Fig. 3.1 Nine variant forms (V1-9) of the visual representation of the hybrid economy

Various sources: listed in accompanying text

V2 (Altman et al. 2006) is a minor variation on V1. It is in colour rather than greyscale and the decorative background has been removed. Note that the colouring does not conform to the logic of hybrid colour. For example, blue and red gives purple not dark red. V3 (Altman 2006) is a colour version of $\mathrm{V} 1$ but with one crucial difference of great logical significance: the decorative background has a border. This poses, once again, the central question of the socioeconomic significance of the bounded space outside the circles. V4 (Altman \& Branchut 2008) is a new variant. The border is preserved but the size of the circles, the sizes of the segments and the colouring has changed. The three sectors are of equal size but the central overlapping segment has grown in importance. The colours of the hybrid segments, while different, still do not conform to the logic of hybrid colour. The removal of the decorative background poses the question, again, of the significance of the bounded white space? 
V5 (Altman 2009) is another significant variation. Segment 7 loses its dominant relative size and the greyscale colouring harmonises with the logic of hybridity: the greater the mix, the darker the grey. But grey is a hybrid mixture of black and white. What interpretation should we give to the unnumbered white segment? Where is the black? V6 (Altman, Biddle et al. 2009) is V4 without the boundary. V7 (Altman, Jordan et al. 2009) is the only one that uses primary colours for the three primary sectors. This is an important innovation. Blue plus yellow is green as shown but thereafter things go wrong. Red plus yellow is orange, not pink. V8 (Altman \& May 2010) is a greyscale version of V5 with the boundary removed and along with it the unnumbered white segment. V9 (Altman 2011b) returns us to V3 without the decorative filler. The restoration of the boundary reposes the central question of the interpretative significance of the bounded outside segment.

When the nine variations are considered as a whole it can be seen that the only constant is the numbering of the segments from 1 to 7 . The shape and colouring of the segments varies as the diameter and relative positioning of the circles changes. Note, too, that the diagrams are either in colour or greyscale - none are in straight black and white.

\section{The pure logic of hybridity: Binary logic versus colourful logic}

What interpretations should we give to these variations? Strict binary logic can help us answer this. Our authority should be none other than John Venn (1894) of Venn diagram fame. He developed his diagrams to give geometrical form to Boole's (1854) binary logic which was expressed in difficult-to-grasp algebraic form.

My V10 (see Fig. 3.2) gets to the heart of the matter in black and white: three sectors, $\mathrm{X}, \mathrm{Y}, \mathrm{Z}$, and eight segments. This is the logic of hybridity in its pure Boolean form. 


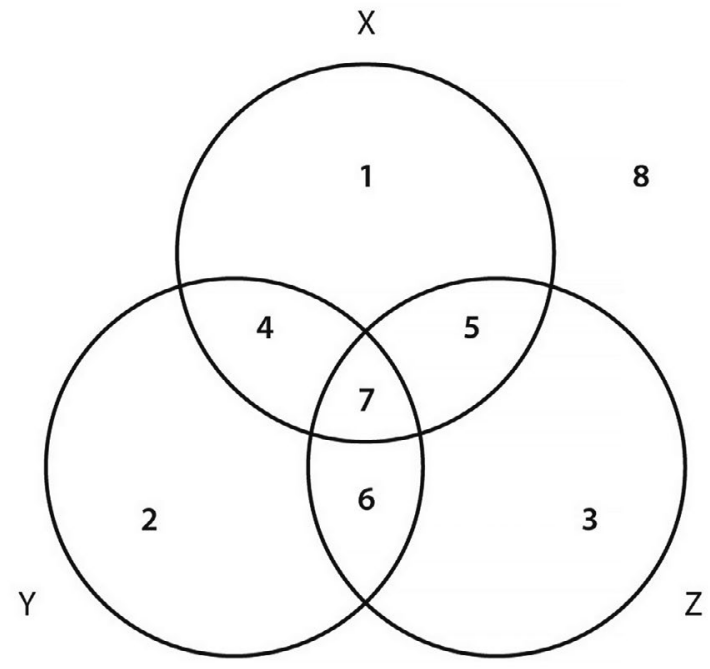

Fig. 3.2 The 'true' binary logic of the hybrid economy in black and white (V10)

Source: Author's depiction

We can use coloured circles to represent the three sectors as shown in V11 (in Fig. 3.3) but this clearly does not change the fact that three overlapping circles create eight logical segments. The three coloured circles and the eight segments remind us that 11 interpretable categories are at stake here.

Filling in the three circles with the three primary colours introduces the logic of colour. This complicates things because it introduces more interpretative possibilities. It has the advantage that it provides a logically rigorous non-biological conception of hybridity. When a yellow pigment is mixed, firstly, with blue it gives green (segment 4) and, secondly, with red it gives orange (segment 5). When blue is mixed with red it gives purple (segment 6). When all three colours are mixed they give black (segment 7) which represents the presence of colour; white, the absence of colour, defines segment 8 . The nonoverlapping primary colours give the segments 1, 2 and 3 as shown in Fig. 3.4. 


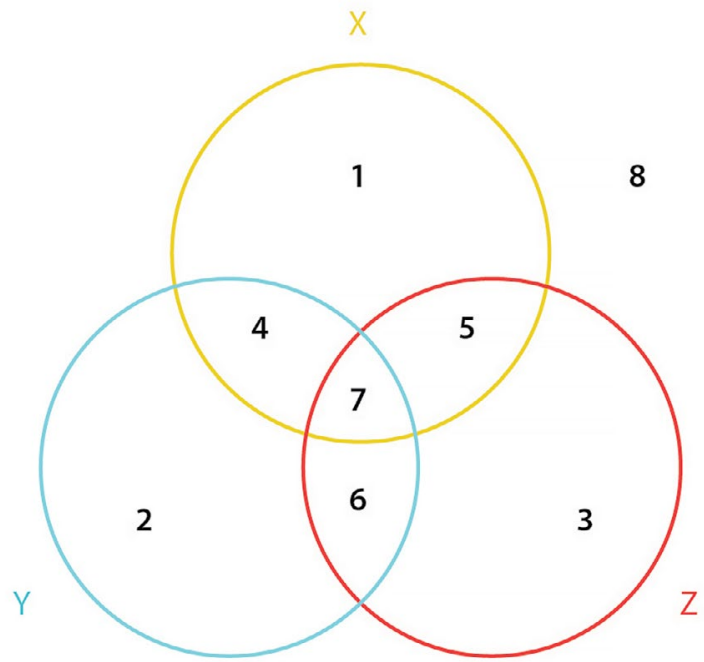

Fig. 3.3 The 'true' binary logic of the hybrid economy showing distinction between the eight bounded white segments and the three coloured sectors (V11)

Source: Author's depiction

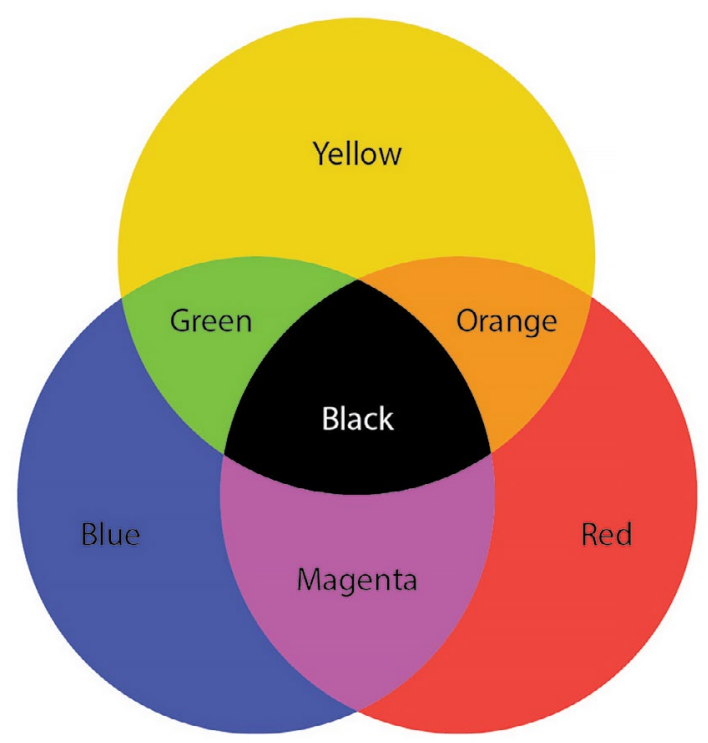

Fig. 3.4 The 'true' binary logic of the hybrid economy showing how the 'true' logic of primary colours creates eight coloured segments Source: Author's depiction 
Two questions are posed: (a) What interpretation can be given to the segments and the 'missing' eighth segment in particular? (b) How should we interpret the relationship between the three sectors in their own right? What additional interpretative possibilities does the logic of colour introduce? For example, hybrid colour presupposes the simultaneous mixing of colours but when the circles are filled in at different points of time there is no mixing; the latest one applied dominates.

\section{Interpretation of the binary logic of the eight segments}

We can now come to the interpretation of the unnamed eighth segment using Jon's definitions of the three primary sectors as means of livelihood: $\mathrm{X}$ refers to income received from the state, $\mathrm{Y}$ to income from the customary sector, and $\mathrm{Z}$ to income received from the market. Boole's zero/one binary logic defines eight segments as shown in colour and in binary numbers as shown in Fig. 3.5.

\begin{tabular}{|c|c|c|c|l|}
\hline Segment & $\mathrm{X}$ & $\mathrm{Y}$ & $\mathrm{Z}$ & Interpretation \\
\hline 1 & 1 & 0 & 0 & livelihood from $\mathrm{X}$ but not $\mathrm{Y}$ or $\mathrm{Z}$ \\
\hline 2 & 0 & 1 & 0 & livelihood from $\mathrm{Y}$ but not $\mathrm{X}$ or $\mathrm{Z}$ \\
\hline 3 & 0 & 0 & 1 & livelihood from $\mathrm{Z}$ but not $\mathrm{Y}$ or $\mathrm{Z}$ \\
\hline 4 & 1 & 1 & 0 & livelihood from $\mathrm{X}$ and $\mathrm{Y}$ but not $\mathrm{Z}$ \\
\hline 5 & 0 & 1 & 1 & livelihood from $\mathrm{Y}$ and $\mathrm{Z}$ but not $\mathrm{X}$ \\
\hline 6 & 1 & 0 & 1 & livelihood from $\mathrm{X}$ and $\mathrm{Z}$ but not $\mathrm{Y}$ \\
\hline 7 & 1 & 1 & 1 & livelihood from $\mathrm{X}$ and $\mathrm{Y}$ and $\mathrm{Z}$ \\
\hline 8 & 0 & 0 & 0 & does not receive income from any sector \\
\hline
\end{tabular}

Fig. 3.5 Interpretation of the eight segments defined by Boole's zero/ one binary logic

Source: Author's depiction

The yellow 100 segment refers to someone who gets income from the state sector but not the other two sectors. The blue 010 segment refers to someone who gets income from the customary sector but not the other two and so on. Thus the black 111 segment refers to someone who gets income, or 'works in', all three sectors. 
Most of Jon's ethnographic examples (Altman 2009: 323) are of people who earn income from all sectors. One example is of a renowned bark painter and respected hunter who, because of his success, receives no income from the state. His interpretation of his own data is that the former work in all seven numbered segments while the latter works in all segments except 1 and 4 .

It follows that the eighth segment refers to someone who does not receive income from any sector. Such people might include young children, the elderly, unemployed young people who do not qualify for unemployment, the homeless, and so on. These people are the ones who must 'beg, borrow or steal', as the saying goes.

It hardly needs to be said that this missing category from Jon's analysis is of profound importance. Their existence raises the question of how they survive. For Nic Peterson the answer is to be found in the phenomenon of 'demand sharing' (Peterson 1993) within the domestic moral economy where marriages of both intra-cultural and intercultural kinds are of great importance (Peterson \& Taylor 2003).

If Jon's Venn diagram representation of the concept of the hybrid economy leaves him open to the charge that he focuses on production to the exclusion of exchange and distribution, then Peterson's notion of the domestic moral economy leaves him open to the charge that he focuses on exchange to the exclusion of production. Clearly both perspectives are needed. We also need to add consumption to the mix.

Jon knows this very well of course. His book (Altman 1987) carefully and meticulously articulates the empirical interrelationships between the spheres of production, consumption, distribution and exchange; the chapters in our joint book on methods (Gregory \& Altman 1989) does the same, thanks, I must say, to Jon's rightful insistence.

Some people call people in the eighth segment 'bludgers'. Guy Standing (2014) calls these people, and others like them whose income is insecure, members of the precariat. His recent book, The precariat: the new dangerous class, does not refer to Jon's work but it could have because Standing's sectoral analysis can be seen as the latest offspring in a lineage of which hybridity is a part. Standing distinguishes six 
sectors which can be reduced to Altman's three sectors. ${ }^{1}$ Given that the family, the market and the state are the three major institutions of modern economic life, this is hardly surprising. Altman's 'customary sector' is just another name for 'family' considered in its broadest sense. Gleaning, another word for foraging, has long been a 'customary' feature of marginal families in hybrid economies in Europe.

\section{Interpretation of the three sectors}

Jon, as we have noted, sometimes conflates the three primary sectors with the three non-overlapping segments numbered 1, 2 and 3. But, as the coloured circles in V11 show (see Fig. 3.3), the three sectors each consists of four segments: sector $\mathrm{X}$, for example, is the sum of segments 1, 4, 5 and 7. In other words, when talking of the three primary sectors we must refer to the areas of the three circles. When these are represented by the primary colours two things can happen. First, the colours can mix and we have the binary logic of hybridity. Another interpretative possibility is that they don't mix, that one or the other of the colours dominates the rest and comes out on top as it were. This analogy takes us from the logic of economic hybridity to that of the general logic of political power - the relations of domination and subordination - and of historically contingent relations between coercion/resistance and persuasion/collaboration. Guha has creatively used colourful logic of this kind in his analysis of peasant insurgency in colonial India (Guha 1983, 1989).

Let us see how it might apply to data Jon has collected on the relative importance of the three sectors over time. Jon's PhD fieldwork has enabled him to present a 'snapshot' picture of the Mumeka economy as he observed that the customary sector was dominant in 1979-80, accounting for 64 per cent of total income earned in the community compared with 26 per cent for the state and 10 per cent for the market

1 'The composition of social income can be broken into six elements. The first is selfproduction, the food, goods and services produced directly, whether consumed, bartered or sold, including what one might grow in a garden or household plot. Second, there is the money wage or the money income received from labour. Third, there is the value of support provided by the family or local community, often by way of informal mutual insurance claims. Fourth, there are enterprise benefits that are provided to many groups of employees. Fifth, there are state benefits, including social insurance benefits, social assistance, discretionary transfers, subsidies paid directly or through employers, and subsidised social services. Finally, there are private benefits derived from savings and investments. Each of these can be subdivided into forms that are more or less secure or assured, and which determine their full value' (Standing 2014: 11). 
sector. Subsequent fieldwork in 2003, albeit from a much shorter time, revealed that the state sector had become dominant providing 57 per cent of all income; the relative importance of the customary sector fell by half to 32 per cent while the market sector remained virtually unchanged at 11 per cent (Altman 2009: 323). Jon does not express this in Venn diagram form for the simple reason that we move from a concern with economic hybridity of segments at a point in time to the relative politico-economic dominance of the three sectors over time. Fig. 3.6 gives a visual representation of these historical changes.

\begin{tabular}{|l|c|c|}
\hline & 1979 & 2003 \\
\hline State & $26 \%$ & $57 \%$ \\
\hline Customary & $64 \%$ & $32 \%$ \\
\hline Market & $10 \%$ & $11 \%$ \\
\hline
\end{tabular}

Fig. 3.6 Interpretation of the three sectors using data on their changing relative importance over time

Source: Author's depiction

Fig. 3.6 looks like a Venn diagram but it is not a 'true' Boolean binary version. It is not a 'false' binary model either. It is a visual representation of political power, of relative domination and subordination. This is an altogether different mongrel.

\section{Conclusion}

Jon's model of the hybrid economy is a completely general one in the non-mainstream tradition of political economy. It is a conceptual framework rather a theory in the sense that it generates questions 
to guide data collection during fieldwork. It is empirical data of this kind, when seen in comparative context, which reveals the specificity of the Australian case. Hybridity is a notion that can be seen in biological or purely logical terms. Jon's notion of hybridity is logical rather than biological but it contains a number of minor logical errors. Venn diagrams are visual representations of Boole's zero/one binary logic. The strict application of this logic defines eight logical spaces, not seven as Jon's diagram shows. Hybridity is best represented by the logic of colour but Jon's use of colour obscures rather than clarifies the logic of hybridity. My identification of these logical errors in his model are not fatal; to the contrary, they improve the model and reveal how the logic of primary and secondary colours can help us think about changing relations of domination and subordination over time.

\section{References}

Altman JC (1987). Hunter-gatherers today: an Aboriginal economy in north Australia, Australian Institute of Aboriginal Studies, Canberra.

Altman JC (2001). Aboriginal economy and social process: the Indigenous hybrid economy and its sustainable development potential. Arena Magazine 56:38-9.

Altman JC (2005). Economic futures on Aboriginal land in remote and very remote Australia: hybrid economies and joint ventures. In Austin-Broos D \& Macdonald G (eds), Culture, economy and governance in Aboriginal Australia, University of Sydney Press, Sydney.

Altman JC (2006). The Indigenous hybrid economy: a realistic sustainable option for remote communities? Topical Issue 2, Centre for Aboriginal Economic Policy Research, The Australian National University, Canberra.

Altman JC (2009). The hybrid economy and anthropological engagements with policy discourse: a brief reflection. The Australian Journal of Anthropology 20:318-29. 
Altman JC (2011a). A genealogy of 'demand sharing': from pure anthropology to public policy. In Musharbash Y \& Barber M (eds), Ethnography and the production of anthropological knowledge: essays in honour of Nicolas Peterson, ANU E Press, Canberra.

Altman JC (2011b). Alleviating poverty in remote Indigenous Australia: the hybrid economy. In Argyrous G \& Stilwell FF (eds), Readings in political economy: economics as a social science, Tilde University Press, Prahran, Victoria.

Altman JC, Biddle N, Buchanan G, Ens E, Jordan K, Kerins S \& May K (2009). Indigenous interests in land and water. In Stone P (ed.), Northern Australia Land and Water Science Review, Australian Government Department of Infrastructure, Transport, Regional Development \& Local Government, Canberra.

Altman JC \& Branchut V (2008). Fresh water in the Maningrida region's hybrid economy: intercultural contestation over values and property rights, Working Paper 46, Centre for Aboriginal Economic Policy Research, The Australian National University, Canberra.

Altman JC, Buchanan G \& Biddle N (2006). The real 'real' economy in remote Australia. In Hunter B (ed.), Recent evidence on Indigenous socioeconomic outcomes: a focus on the 2002 NATSISS, ANU E Press, Canberra.

Altman JC, Jordan K, Munro I, Ryan M \& Mirikul M (2009). Maningrida region, Arnhem Land, Northern Territory. In Green D, Jackson S, \& Morrison J (eds), Risks from climate change to Indigenous communities in the tropical north of Australia, Australian Government Department of Climate Change, Canberra.

Altman JC \& May K (2010). Poverty alleviation in remote Indigenous Australia. In Minnerup G \& Solberg PP (eds), First world, First Nations: internal colonialism and Indigenous self-determination in northern Europe and Australia, Sussex Academic Press, Eastbourne, UK.

Ballard R (2012). Geographies of development II: cash transfers and the reinvention of development for the poor. Progress in Human Geography 37(6):811-21. 
Boole G (1854). An investigation of the laws of thought, on which are founded the mathematical theories of logic and probabilities, Dover Publications Inc., New York.

Gregory CA \& Altman JC (1989). Observing the economy, Routledge, London.

Guha R (1983). Elementary aspects of peasant insurgency in colonial India, Oxford University Press, Delhi.

Guha R (1989). Dominance without hegemony and its historiography. In Guha R (ed.), Subaltern studies VI: writings on South Asian history and society, Oxford University Press, Delhi.

Peterson N (1993). Demand sharing: reciprocity and the pressure for generosity among foragers. American Anthropologist 95(4):860-74.

Peterson N \& Taylor J (2003). The modernising of the Indigenous domestic moral economy: kinship, accumulation and household composition. The Asia Pacific Journal of Anthropology 4(1):105-22.

Standing G (2014). The precariat: the new dangerous class. Bloomsbury, London.

Venn J (1894). Symbolic logic. Chelsea Publishing, New York.

Yang MM (2000). Putting global capitalism in its place: economic hybridity, Bataille, and ritual expenditure. Current Anthropology 41(4):477-509. 
This text is taken from Engaging Indigenous Economy: Debating diverse approaches, edited by Will Sanders, published 2016 by ANU Press, The Australian National University, Canberra, Australia. 